\title{
Monitoring of the Water Levels in the Wetlands of Fourmile Branch Near the F- and H-Areas of SRS: FY97
}

by

K. L. Dixon

Westinghouse Savannah River Company

Savannah River Site

Aiken, South Carolina 29808

A. L. Schwartzman

This paper was prepared in connection with work done under the above contract number with the U.S. Department of Energy. By acceptance of this paper, the publisher and/or recipient acknowledges the U.S. Government's right to retain a nonexclusive, royalty-free license in and to any copyright covering this paper, along with the right to reproduce and to authorize others to reproduce all or part of the copyrighted paper. 


\section{Monitoring of the Water Levels in the Wetlands of Fourmile Branch Near the F- and H-Areas of SRS: FY97}

Kenneth L. Dixon

Adam L. Schwartzman

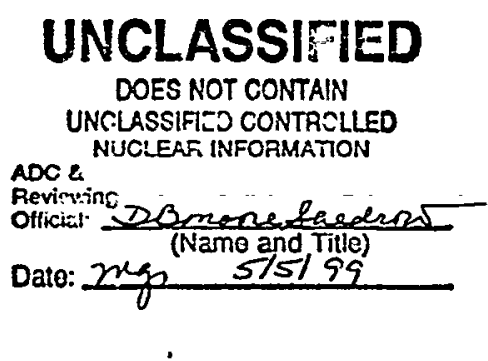

Westinghouse Savannah River Company

Savannah River Site

Aiken, SC 29808

Prepared for the U.S. Department of Energy under contract no. DE-AC09-96SR18500 


\section{DISCLAIMER}

This report was prepared as an account of work sponsored by an agency of the United States Government. Neither the United. States Government nor any agency thereof, nor any of their employees, makes any warranty, express or implied, or assumes any legal liability or responsibility for the accuracy, completeness, or usefulness of any information, apparatus, product, or process disclosed, or represents that its use would not infringe privately owned rights. Reference herein to any specific commercial product, process, or service by trade name, trademark, manufacturer, or otherwise does not necessarily constitute or imply its endorsement, recommendation, or favoring by the United States Government or any agency thereof. The views and opinions of authors expressed herein do not necessarily state or reflect those of the United States Government or any agency thereof.

This report has been reproduced directly from the best available copy.

Available to DOE and DOE contractors from the Office of Scientific and Technical Information, P.O. Box 62, Oak Ridge, TN 37831; prices available from (615) 576-8401.

Available to the public from the National Technical Information Service, U.S. Department of Commerce, 5285 Port Royal Road, Springfield, VA 22161. 


\section{DISCLAIMER}

Portions of this document may be illegible in electronic image products. Images are produced from the best available original document. 
WSRC-TR-97-00318

Rev. 0

September 1997

\section{Monitoring of the Water Levels in the Wetlands of Fourmile Branch Near the F- and H-Areas of SRS: FY97}

Kenneth L. Dixon

Adam L. Schwartzman

Prepared for the U.S. Department of Energy under contract no. DE-AC09-96SR18500- 


\title{
Monitoring of the Water Levels in the Wetlands of Fourmile Branch Near the F- and H-Areas of SRS: FY97
}

\author{
K. L. Dixon and A. L. Schwartzman \\ Savannah River Technology Center \\ Westinghouse Savannah River Company \\ Aiken, SC 29802
}

\section{Executive Summary}

A remediation system for the groundwater in $\mathrm{F}$ - and $\mathrm{H}$-Areas is being implemented in accordance with a Resource Conservation and Recovery Act (RCRA) Hazardous Waste Part B Permit. The design of this system includes a network of extraction and injection wells to maintain hydraulic control of the 10,000 $\mathrm{pCi} / \mathrm{ml}$ tritium plume. Drawdown of the water table near the extraction wells may result in drying of a portion of the wetland areas near Fourmile Branch. In order to assess potential impacts of the remediation effort on the riparian wetland system, a network of twenty three piezometers was installed. This network of piezometers was established along the groundwater outcrop (i.e., seepline) for the water table aquifer, specifically targeting those areas closest to the extraction wells. The purpose of the piezometer network is to establish baseline hydraulic head data for the water table aquifer at the F- and H-Area seeplines prior to startup of the groundwater extraction/injection remediation system.

Monthly water level measurements were taken from each piezometer, and are presented in this report. Additionally, some piezometers were instrumented with data loggers for continuous monitoring of water levels. The purpose of continuous monitoring is to investigate the natural variability of water levels in the riparian wetland system of Fourmile Branch. Of particular interest is the variation in water levels associated with rainfall events, and evapotranspiration demand. The frequency, magnitude, and duration of these natural variations are unknown, and more frequent monitoring is required to assess them. Additionally, following startup of the extraction/injection system, increased variation in the hydrologic system in and around the wetlands is expected. These variations are expected to be more pronounced at those locations closest to the extraction wells. Thus, the piezometers closest to the extraction wells were chosen for instrumentation. The establishment of a baseline for the natural variations, as well as for the variations associated with the remediation system startup, will allow for the determination of an appropriate monitoring frequency for the remaining piezometers.

The information in this report was developed during the course of work under Contract No. DE-AC09-96SR18500 with the U. S. Department of Energy. 


\section{Background}

Seepage basins in the F- and $\mathrm{H}$-Areas of the Savannah River Site (SRS) received low-level radioactive waste effluent from the chemical separations processes in the General Separations Area. This waste effluent consisted mostly of sodium hydroxide, nitric acid, low levels of various radionuclides (primarily tritium), and some metals (Killian et al., 1985a and b). Discharges to the seepage basins were discontinued in 1988 and the basins were capped and sealed in 1990. As a result of basin operations, groundwater beneath and down gradient of the basins was contaminated. The contamination is located primarily in the water table aquifer (Aquifer Zone $\mathrm{IB}_{2}$ ) and in the Barnwell/McBean Aquifer (Aquifer Zone $\mathrm{IB}_{1}$ ). In both $\mathrm{F}$ - and $\mathrm{H}$-Area near the seepage basins, groundwater in Aquifer Zone $\mathrm{IB}_{2}$ and $\mathrm{MB}_{1}$ flows toward Fourmile Branch. Aquifer Zone $\mathrm{IB}_{2}$ discharges to the wetlands and Fourmile Branch whereas Aquifer Zone $\mathrm{IB}_{\mathrm{I}}$ discharges primarily to Fourmile Branch. Contaminants originating from the seepage basins have been detected in shallow groundwater outcrops (i.e. the seepline) in the wetlands of Fourmile Branch in both $\mathrm{F}$-and $\mathrm{H}$-Area (Haselow et al., 1990; Dixon et al., 1993a; Dixon.et al., 1993b, Dixon et al., 1994).

A remediation system for the groundwater in Fand $\mathrm{H}$-Areas is being implemented in accordance with a Resource Conservation and Recovery Act (RCRA) Hazardous Waste Part B Permit. The design of this system includes a network of extraction and injection wells to maintain hydraulic control of the $10,000 \mathrm{pCi} / \mathrm{ml}$ tritium plume.

The remediation system in F-Area will consist of a total of seventeen wells within Aquifer Zone $\mathrm{IIB}_{2}$; nine extraction and eight injection wells. The remediation system in $\mathrm{H}$-Area will consist of twenty three wells within Aquifer Zone $\mathrm{IB}_{2}$, fifteen extraction wells and eight injection wells. Figures 1 and 2 show the locations of the extraction/injection wells for the water table aquifer (Aquifer Zone $\mathrm{MB}_{2}$ ) in F-
Area and $\mathrm{H}$-Area, respectively. The extraction wells are prefixed "FEX" and "HEX" and the injection wells are prefixed "FIN" and "HIN

Decreases in water levels associated with drawdown near the extraction wells may result in drying of a portion of the wetlands, and an overall movement of the seepline towards Fourmile Branch. Chronic depression of the water table at the wetlands, and the associated reversal in direction of groundwater flow, may result in alterations of the wetland plant and animal communities in this area. Further, changes in the hydrology of the wetlands will impact contaminant transport and contaminant concentrations at the new seeplines.

To aid in assessing the impacts of the remediation system on the wetlands, changes in water levels in and near the wetlands must be monitored. Baseline hydraulic head data for the water table aquifer at both the $\mathrm{F}$ - and $\mathrm{H}$-Area seeplines should be collected prior to initiation of groundwater extraction and continued following startup. This is critical to identifying the source of any wetland impacts that may be observed following startup of the extraction/injection system. To accomplish this, a network of piezometers was established in the wetlands of Fourmile Branch in both $\mathrm{F}$ - and $\mathrm{H}$ Areas in 1996 (Dixon, 1996). Currently, this network consists of twenty three piezometers at seventeen different locations. The purpose of this report is to detail the results of monthly water level measurements.

\section{METHODS}

A total of twenty three water table piezometers have been installed at seventeen locations in the wetlands of Fourmile Branch near F- and HAreas. During January and May of 1996, twenty piezometers were installed at fourteen locations in a network in both $\mathrm{F}$ - and $\mathrm{H}$-Area (FPZ and HPZ prefixes). The network was designed to outline the current seepline focusing on those areas expected to be most impacted by the remediation system (Figures 1 and 2). At locations with heterogeneous stratigraphy, 
piezometers were installed in clusters. The deeper piezometers were designated with the suffix " $A$ ", and the shallow piezometers were designated with the suffix " $B$ ". During June 1997, three additional piezometers were installed in a reference area located in the wetlands of Fourmile Branch, but outside the area of influence of the remediation system (Figure 3). These reference piezometers (FHR prefix) were intended to provide a baseline for comparison to water level changes observed in those piezometers located within the area of influence of the groundwater remediation system.

With the exception of FPZ003A, all piezometers were installed using hand augering equipment ( 3 1/4" bucket auger) according to WSRC-3Q5 (Chapter 7) procedures. Location FPZ003A is in an upland area, and due to the depth to the water table at this location, it was installed using a hollow stem augering method.

A detailed discussion of the installation methods for all piezometers but the reference piezometers has been presented by Dixon (1996). The installation methods for the reference piezometers were essentially the same as those described by Dixon (1996) and are not repeated here.

Table 1 gives the piezometer construction information for all the piezometers (FPZ, HPZ, and FHR series).

\section{Measurement of Water Levels}

Water levels in the piezometers were measured monthly using an electric water level tape.

From these measurements, the elevation of the water table was determined for each location. Additionally, the water level of Fourmile Branch was measured at two locations. These two stream sites were located where Road C4 and Road El cross Fourmile Branch.

\section{Instrumentation of Selected Piezometers}

In an effort to investigate the natural variability of water levels in the riparian wetland system of Fourmile Branch, several piezometers were equipped with data logging equipment to allow for continuous water level monitoring. Of particular interest is the variation in water levels associated with rainfall events, and evapotranspiration demand. The frequency, magnitude, and duration of these natural variations are unknown, and more frequent monitoring is required to assess them. Additionally, following startup of the extraction/injection system, increased variation in the hydrologic system in and around the wetlands is expected. These variations are expected to be more pronounced at those locations closest to the extraction wells. Thus, the piezometers closest to the extraction wells were chosen for instrumentation. The establishment of a baseline for the natural variations, as well as for the variations associated with the remediation system startup; will allow for the determination of an appropriate monitoring frequency for the remaining piezometers.

The piezometers selected for instrumentation are shown in Figures 1 and 2, and are listed in Table 2. Table 2 also gives the date of instrumentation for each piezometer. Each of the selected piezometers was equipped with a pressure transducer ( 5 psig range) controlled by a Campbell Scientific, Inc. CR10X data logger. Additionally, at locations FPZ005A and HPZ003A, a tipping bucket rain gage was connected to the CR10X to provide rainfall data.

Water level measurements were monitored continuously at each location and averaged every thirty minutes. Additionally, rainfall amounts were totaled every thirty minutes for both $\mathrm{F}$ - and $\mathrm{H}$-Areas. 


\section{Results and Discussion}

Results from the monthly water level measurements for the period of September 1996 through August 1997 are presented in Tables 3A and $3 \mathrm{~B}$. The minimum, maximum, and average water level elevation, and standard deviation was computed for each location and is presented in Table 4. Table 4 also gives the average water level in each piezometer relative to ground elevation. Hydrographs for each location were created and are presented in Figures 4 through 17.

Preliminary evaluation of data collected from the continuous monitoring effort has confirmed an expected correlation between rainfall events and water levels in the wetlands. Figures 18 and 19 represent typical plots of data collected from the piezometers. From these figures, it can be seen that the response to rainfall was immediate as well as transient; however, more detailed study over a longer period of time is needed to. determine the magnitude and duration of the transient surge in water levels associated with rainfall.

In addition to the rainfall response, diurnal fluctuations in water level due to evapotranspiration are also clearly shown in Figures 18 and 19. A periodic decline in water levels is observed during the middle portions of each day, which may be attributed to increased evapotranspiration demand. During the nighttime hours when evapotranspiration demands are lowest, the water levels recover. As seen in Figure 18, fluctuations of $0.1 \mathrm{ft}$ are not uncommon during peak evapotranspiration periods.

Figures 18 and 19 demonstrate the natural variability in water levels in the wetlands of Fourmile Branch. In order to completely define baseline conditions for the wetlands, the magnitude, frequency, and duration of the variations must be quantified. Long term assessment of data collected from the instrumented piezometers will allow for a more detailed analysis of the natural variations associated with these types of wetland systems.

\section{References}

Dixon, K. L. 1996. Monitoring of the Water Levels in the Wetlands of Fourmile Branch Near the F- and H-Areas of SRS. WSRC-TR-960289. Westinghouse Savannah River Company, Savannah River Technology Center, Aiken SC.

Dixon, K. L., V. A. Rogers, and B. B. Looney. 1993a. Results of the quarterly tritium survey of Four Mile Creek and its seeplines in the F- and H- Areas of SRS: September 1993. WSRC-TR93-286-ESS, Rev. 1, Westinghouse Savannah River Company, Savannah River Technology Center, Aiken SC.

Dixon, K. L. and V. A. Rogers. 1993b. Semiannual sampling of Fourmile Branch and its seeplines in the $\mathrm{F}$ - and $\mathrm{H}$-Areas of SRS: July 1992. WSRC-TR-93-289, Westinghouse Savannah River Company, Savannah River Technology Center, Aiken SC.

Friday, G. P. 1997. Environmental Summary of the F- and H-Area Seepage Basins Groundwater Remediation Project, Savannah River Site. WSRC-TR-97-0130, Westinghouse Savannah River Company, Aiken, SC.

Haselow, J. S., M. Harris, B. B. Looney, N. V. . Halverson, and J. B. Gladden. 1990. Analysis of soil and water at the Four Mile Creek seepline near the F- and H-Areas of SRS. WSRC-RP-90. 0591, Westinghouse Savannah River Company, Savannah River Technology Center, Aiken SC.

Killian, T.H., N.L. Kolb, P. Corbo, and I.W. Marine. 1985a. F-Area seepage basins. DPST85-704, E.I. du Pont de Nemours and Company, Savannah River Laboratory, Aiken, SC.

Killian, T.H., N.L. Kolb, P. Corbo, and I.W. Marine. 1985b. H-Area seepage basins. DPST85-706, E.I. du Pont de Nemours and Company, Savannah River Laboratory, Aiken, SC. 


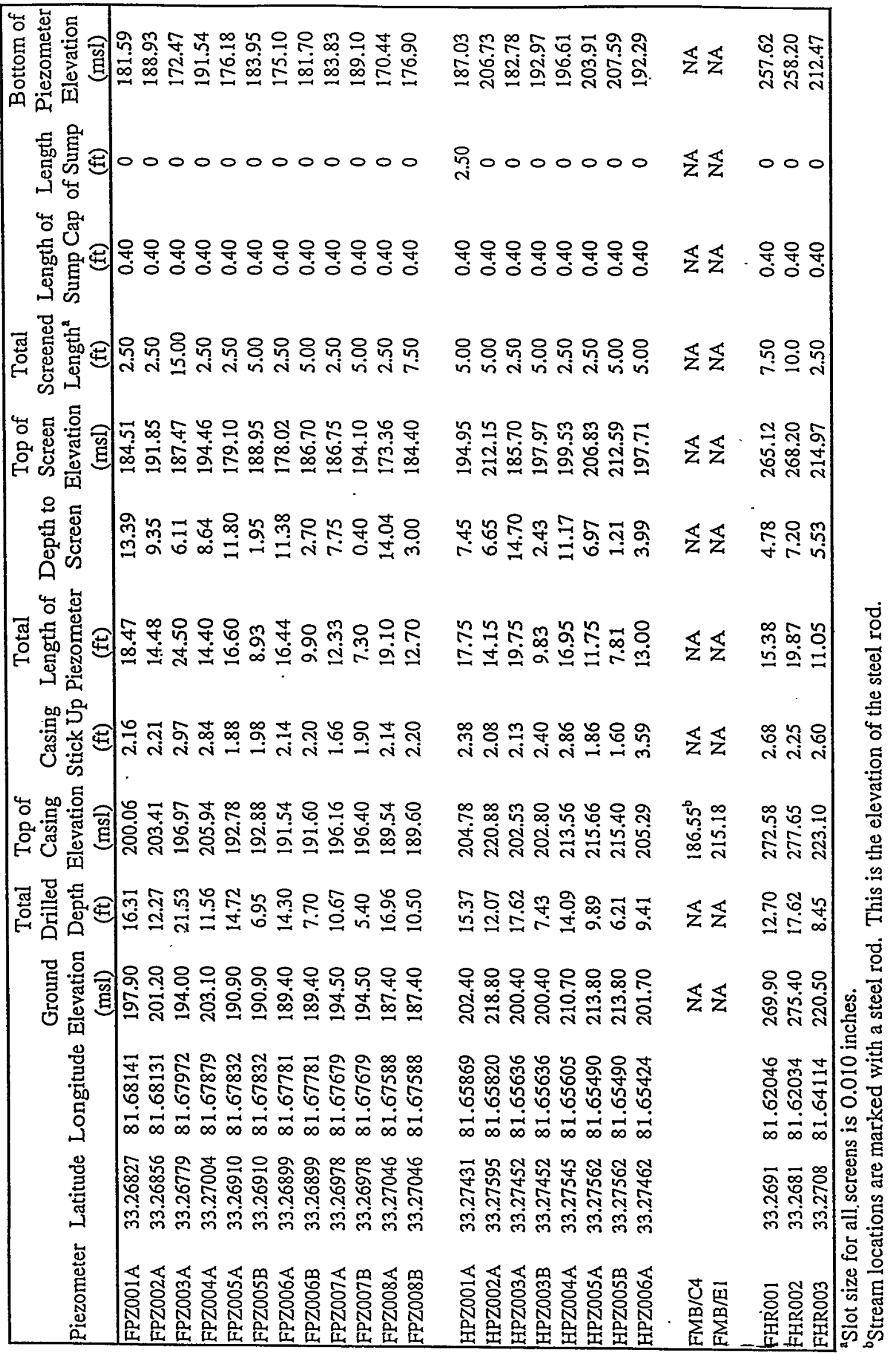


Table 2. List of Piezometers having data logging.

\begin{tabular}{l|c|c|c}
\hline Piezometer & Latitude & Longitude & Installation Date \\
\hline FPZ001A & 33.26827 & 81.68141 & September 1996 \\
\hline FPZ002A & 33.26856 & 81.68131 & September 1996 \\
\hline FPZ004A & 33.27004 & 81.67879 & July 1996 \\
\hline FPZ005A & 33.26910 & 81.67832 & July 1996 \\
\hline FPZ006A & 33.26899 & 81.67781 & July 1996 \\
\hline & & & \\
\hline HPZ002A & 33.27595 & 81.65820 & September 1996 \\
\hline HPZ003A & 33.27452 & 81.65636 & August 1996 \\
\hline HPZ004A & 33.27545 & 81.65605 & August 1996 \\
\hline HPZ005A & 33.27562 & 81.65490 & September 1996 \\
\hline
\end{tabular}


Table 3. Water Level Measurements at Individual Piezometers, September 1996 - February 1997

\begin{tabular}{|c|c|c|c|c|c|c|c|}
\hline $\begin{array}{c}\text { Piezometer } \\
\text { ID } \\
\end{array}$ & \multicolumn{6}{|c|}{$\begin{array}{c}\text { Water Level Elevations } \\
(\mathrm{msl})\end{array}$} & \multirow[t]{2}{*}{$\begin{array}{c}\text { Ground } \\
\text { Elevation } \\
(\mathrm{msl})\end{array}$} \\
\hline & Sep-96 & Oct-96 & Nov-96 & Dec-96 & Jan-97 & Feb-97 & \\
\hline FPZ001A & 197.90 & 197.98 & 197.96 & 197.97 & 197.96 & 198.02 & 197.90 \\
\hline FPZ002A & 201.30 & 201.26 & 201.18 & 201.15 & 201.19 & 201.96 & 201.20 \\
\hline FPZ003A & 188.49 & 187.84 & 187.92 & 188.33 & 189.29 & 191.22 & 194.00 \\
\hline FPZ004A & 201.20 & 201.24 & 201.18 & 201.14 & 201.14 & 201.62 & 203.10 \\
\hline FPZ005A & 191.02 & 191.12 & 191.10 & 191.13 & 191.17 & 191.24 & 190.90 \\
\hline FPZ005B & 191.16 & 191.18 & 191.16 & 191.18 & 191.19 & 191.19 & 190.90 \\
\hline FPZ006A & 189.34 & 188.88 & 189.04 & 189.12 & 189.33 & 189.67 & 189.40 \\
\hline FPZ006B & 188.76 & 188.72 & 188.86 & 188.95 & 189.11 & 189.28 & 189.40 \\
\hline FPZ007A & 192.91 & 192.91 & 192.95 & 193.02 & 193.14 & 193.34 & 194.50 \\
\hline FPZ007B & 194.26 & 194.31 & 194.12 & 194.38 & 194.4 & 194.42 & 194.50 \\
\hline FPZ008A & 187.59 & 187.60 & 187.56 & 187.62 & 187.66 & 187.71 & 187.40 \\
\hline FPZ008B & 187.56 & 187.60 & 187.61 & 187.62 & 187.61 & 187.62 & 187.40 \\
\hline HPZ001A & 202.28 & 202.32 & 202.33 & 202.33 & 202.35 & 202.38 & 202.40 \\
\hline $\mathrm{HPZ} 002 \mathrm{~A}$ & 217.96 & 217.86 & 217.80 & 217.82 & 218.05 & 218.70 & 218.80 \\
\hline HPZ003A & 200.79 & 201.00 & 201.05 & 201.39 & 201.34 & 201.53 & 200.40 \\
\hline HPZO03B & 200.56 & 200.88 & 200.89 & 200.88 & 200.90 & 200.92 & 200.40 \\
\hline HPZ004A & 209.96 & 210.23 & 210.27 & 210.28 & 210.29 & 210.35 & 210.70 \\
\hline HPZ005A & 212.21 & 212.14 & 212.56 & 212.64 & 212.95 & 213.35 & 213.80 \\
\hline HPZ005B & 213.08 & 212.08 & 212.62 & 212.70 & 213.07 & 213.44 & 213.80 \\
\hline HPZ006A & 202.11 & 202.02 & 201.94 & 201.72 & 201.82 & 201.94 & 201.70 \\
\hline $\mathrm{FMB} / \mathrm{C} 4$ & 178.24 & 178.19 & 177.78 & 177.81 & 177.82 & 178.21 & $\mathrm{NA}$ \\
\hline FMB/E1 & 214.35 & 214.39 & 214.44 & 214.47 & 214.47 & 214.67 & $\mathrm{NA}$ \\
\hline FHR001 & $\mathrm{NA}$ & $\mathrm{NA}$ & $\mathrm{NA}$ & $\mathrm{NA}$ & NA & NA & NA \\
\hline FHR002 & NA & NA & NA & NA & NA & $\mathrm{NA}$ & $\mathrm{NA}$ \\
\hline FHR003 & NA & $\mathrm{NA}$ & $\mathrm{NA}$ & NA & NA & $\mathrm{NA}$ & NA \\
\hline
\end{tabular}


Table 4. Water Level Measurements at Individual Peizometers, March 1997- August 1997

\begin{tabular}{|c|ccccccc|c|}
\hline $\begin{array}{c}\text { Piezometer } \\
\text { ID }\end{array}$ & \multicolumn{7}{|c|}{$\begin{array}{c}\text { Water Level Elevations } \\
\text { (msl) }\end{array}$} & $\begin{array}{c}\text { Ground } \\
\text { Elevation } \\
\text { (msl) }\end{array}$ \\
\hline & Mar-97 & Apr-97 & May-97 & Jun-97 & Jul-97 & Aug-97 & \\
FPZ001A & 197.96 & 197.96 & 197.91 & 197.89 & 197.96 & 197.92 & 197.90 \\
FPZ002A & 201.39 & 200.91 & 200.96 & 200.91 & 201.26 & 200.86 & 201.20 \\
FPZ003A & 189.55 & 188.61 & 188.74 & 188.36 & 189.15 & 187.27 & 194.00 \\
FPZ004A & 201.31 & 201.22 & 200.98 & 200.88 & 201.01 & 200.79 & 203.10 \\
FPZ005A & 191.18 & 191.17 & 191.41 & 191.07 & 191.11 & 191.05 & 190.90 \\
FPZ005B & 191.18 & 191.22 & 191.21 & 191.18 & 191.15 & 191.13 & 190.90 \\
FPZ006A & 189.32 & 189.43 & 189.00 & 188.81 & 189.09 & 188.82 & 189.40 \\
FPZ006B & 189.12 & 189.19 & 188.84 & 188.56 & 188.89 & 188.70 & 189.40 \\
FPZ007A & 193.11 & 193.20 & 192.93 & 192.77 & 192.96 & 192.81 & 194.50 \\
FPZ007B & 194.40 & 194.42 & 194.37 & 194.27 & 194.35 & 194.30 & 194.50 \\
FPZ008A & 187.64 & 187.68 & 187.62 & 187.60 & 187.60 & 187.59 & 187.40 \\
FPZ008B & 187.60 & 187.62 & 187.62 & 187.55 & 187.58 & 187.60 & 187.40 \\
& & & & & & & \\
HPZ001A & 202.38 & 202.37 & 202.32 & 202.22 & 202.33 & 202.28 & 202.40 \\
HPZ002A & 218.39 & 218.38 & 217.84 & 217.62 & 218.00 & 217.48 & 218.80 \\
HPZ003A & 201.38 & 201.38 & 201.13 & 201.23 & 201.40 & 201.23 & 200.40 \\
HPZ003B. & 200.86 & 200.89 & 200.71 & 200.49 & 200.53 & 200.55 & 200.40 \\
HPZ004A & 210.26 & 210.28 & 209.76 & 210.08 & 210.08 & 210.06 & 210.70 \\
HPZ005A & 212.81 & 213.38 & 212.60 & 211.94 & 212.88 & 211.91 & 213.80 \\
HPZ005B & 212.90 & 213.54 & 212.85 & 211.89 & 212.98 & 213.90 & 213.80 \\
HPZ006A & 201.89 & 202.02 & 201.93 & 202.14 & 202.29 & 202.24 & 201.70 \\
FMB/C4 & 178.03 & 178.31 & 178.39 & 178.4 & 178.81 & 178.41 & NA \\
FMB/E1 & 214.48 & 214.64 & 214.41 & 214.38 & 207.18 & 214.35 & NA \\
FHR001 & & & & & & & \\
FHR002 & NA & NA & NA & NA & 268.99 & 268.58 & 269.90 \\
FHR003 & NA & NA & NA & NA & 272.46 & 271.05 & 275.40 \\
FPA & NA & 219.87 & 219.90 & 220.50 \\
\hline
\end{tabular}


Table 5. Average Water Level Measurements for the Period of September 1996 to August 1997.

\begin{tabular}{|c|c|c|c|c|c|}
\hline $\begin{array}{l}\text { Piezometer } \\
\text { ID }\end{array}$ & $\begin{array}{l}\text { Minimum } \\
\text { Water Level } \\
\text { (msl) }\end{array}$ & $\begin{array}{c}\text { Maximum } \\
\text { Water Level } \\
(\mathrm{msl}) \\
\end{array}$ & $\begin{array}{c}\text { Average } \\
\text { Water Level } \\
\text { (msl) }\end{array}$ & $\begin{array}{c}\text { Standard } \\
\text { Deviation } \\
(\mathrm{ft}) \\
\end{array}$ & $\begin{array}{l}\text { Water Level Relative } \\
\text { to Ground Elevation } \\
\text { (ft) }\end{array}$ \\
\hline FPZ001A & 197.89 & 198.02 & 197.95 & 0.09 & .05 \\
\hline FPZ002A & 200.86 & 201.96 & 201.19 & 0.78 & -.01 \\
\hline FPZ003A & 187.27 & 191.22 & 188.73 & 2.79 & -5.27 \\
\hline FPZ004A & 200.79 & 201.62 & 201.14 & 0.59 & -1.96 \\
\hline FPZ005A & 191.02 & 191.41 & 191.15 & 0.28 & 0.25 \\
\hline FPZ005B & 191.13 & 191.22 & 191.18 & 0.06 & 0.28 \\
\hline FPZ006A & 188.81 & 189.67 & 189.15 & 0.61 & -0.25 \\
\hline FPZ006B & 188.56 & 189.28 & 188.92 & 0.51 & -0.48 \\
\hline FPZ007A & 192.77 & 193.34 & 193.00 & 0.40 & -1.50 \\
\hline FPZ007B & 194.12 & 194.42 & 194.33 & 0.21 & -0.17 \\
\hline FPZ008A & 187.56 & 187.71 & 187.62 & 0.11 & 0.22 \\
\hline FPZ008B & 187.55 & 187.62 & 187.60 & 0.05 & 0.20 \\
\hline HPZ001A & 202.22 & 202.38 & 202.32 & 0.11 & -0.08 \\
\hline HPZ002A & 217.48 & 218.70 & 217.99 & 0.86 & -0.81 \\
\hline $\mathrm{HPZ003A}$ & 200.79 & 201.53 & 201.24 & 0.52 & 0.84 \\
\hline HPZ003B & 200.49 & 200.92 & 200.76 & 0.30 & 0.36 \\
\hline HPZ004A & 209.76 & 210.35 & 210.16 & 0.42 & -0.1 \\
\hline HPZ005A & 211.91 & 213.38 & 212.61 & 1.04 & -1.19 \\
\hline HPZ005B & 211.89 & 213.90 & 212.92 & 1.42 & -0.88 \\
\hline HPZ006A & 201.72 & 202.29 & 202.01 & 0.40 & 0.31 \\
\hline $\mathrm{FMB} / \mathrm{C} 4$ & 177.78 & 178.81 & 178.20 & 0.73 & $\mathrm{NA}$ \\
\hline $\mathrm{FMB} / \mathrm{E} 1$ & 207.18 & 214.67 & 213.85 & 5.30 & $\mathrm{NA}$ \\
\hline FHR001 ${ }^{b}$ & 268.58 & 268.99 & 268.79 & 一 & 1.11 \\
\hline FHR002 & 271.05 & 272.46 & 271.76 & - & 3.64 \\
\hline FHR003 & 219.87 & 219.90 & 219.89 & - & .61 \\
\hline
\end{tabular}

${ }^{2}$ Positive values indicate the water level is above ground elevation. Negative values indicate the water level is below ground elevation.

${ }^{b}$ FHR001, FHR002, and FHR003 contain only two measurements. 


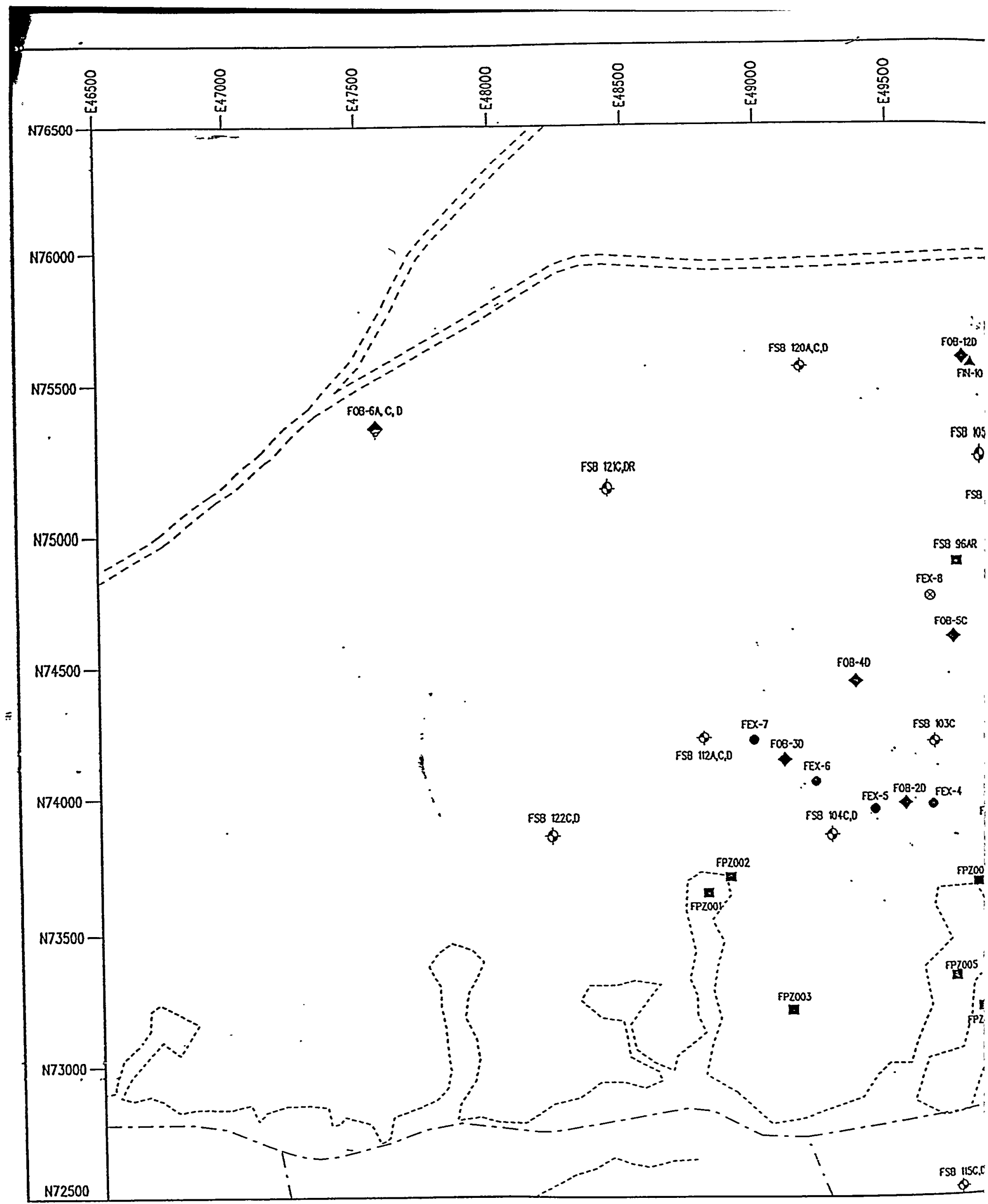

Figure 1. Extraction/injection well locations and piezometer locations for Aquifer Zone IIB 2 (water table) in F-Area. 


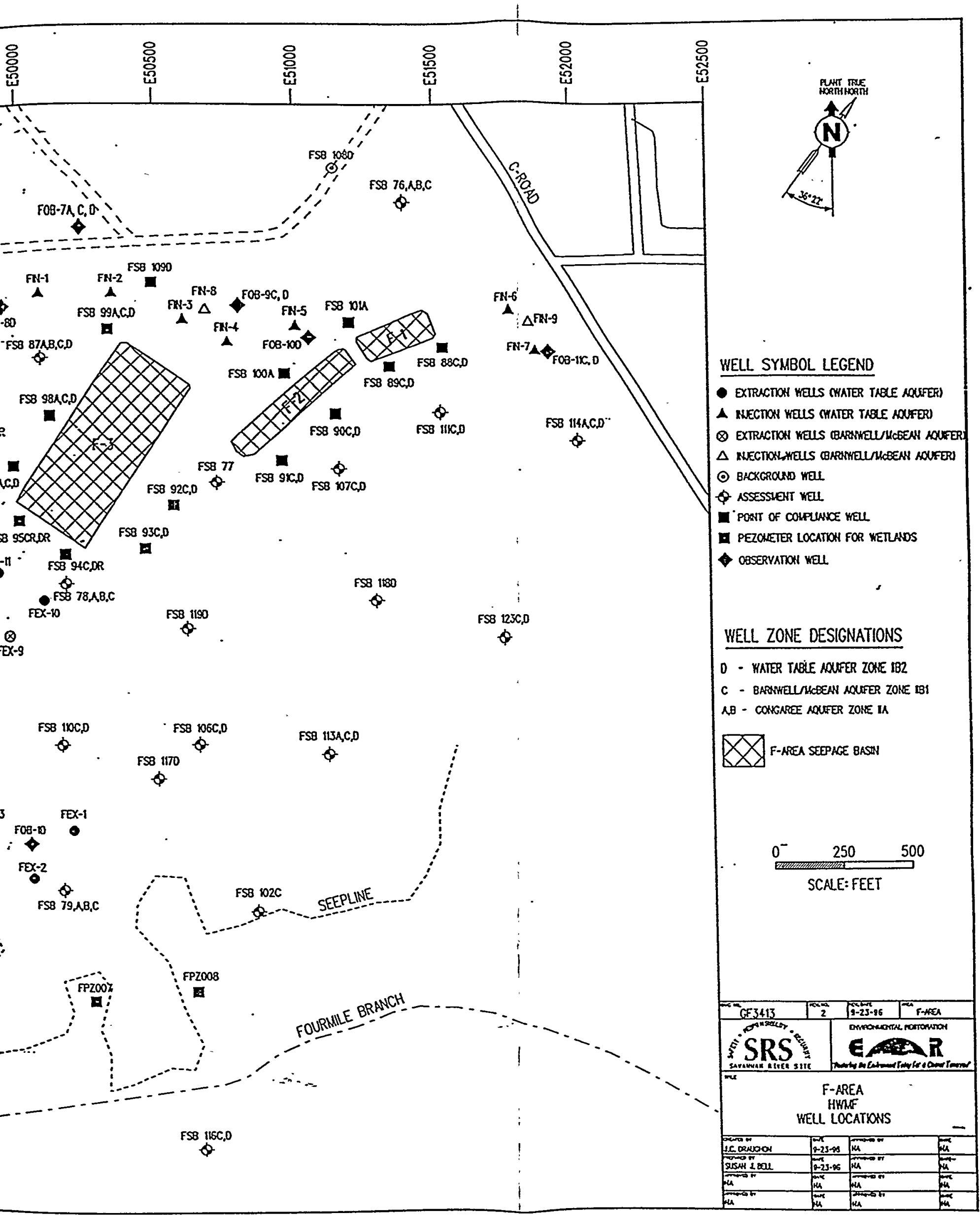




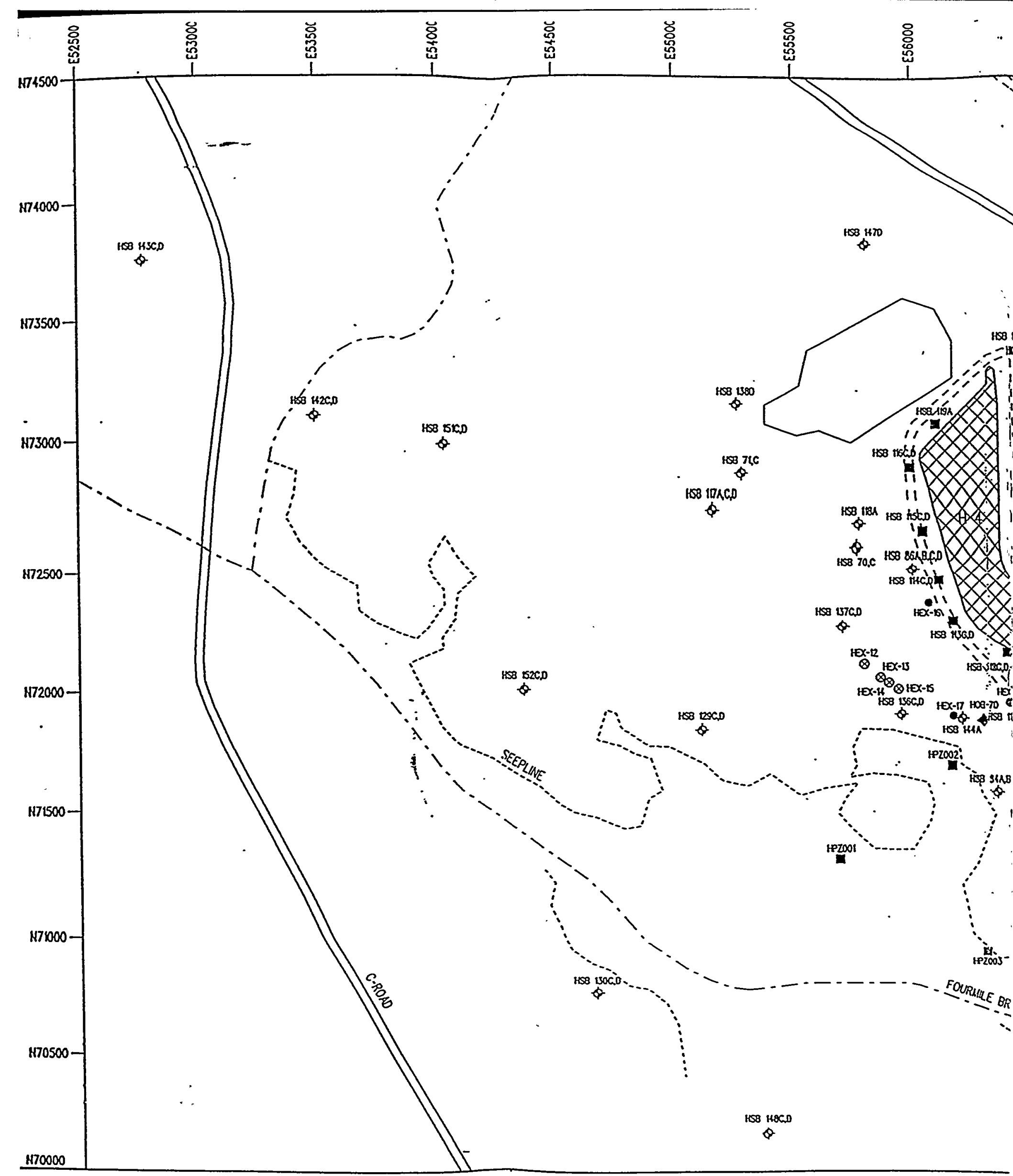

Figure 2. Extraction/injection well locations and piezometer locations for Aquifer Zone $\mathrm{IIB}_{2}$ (water table) in H-Area. 


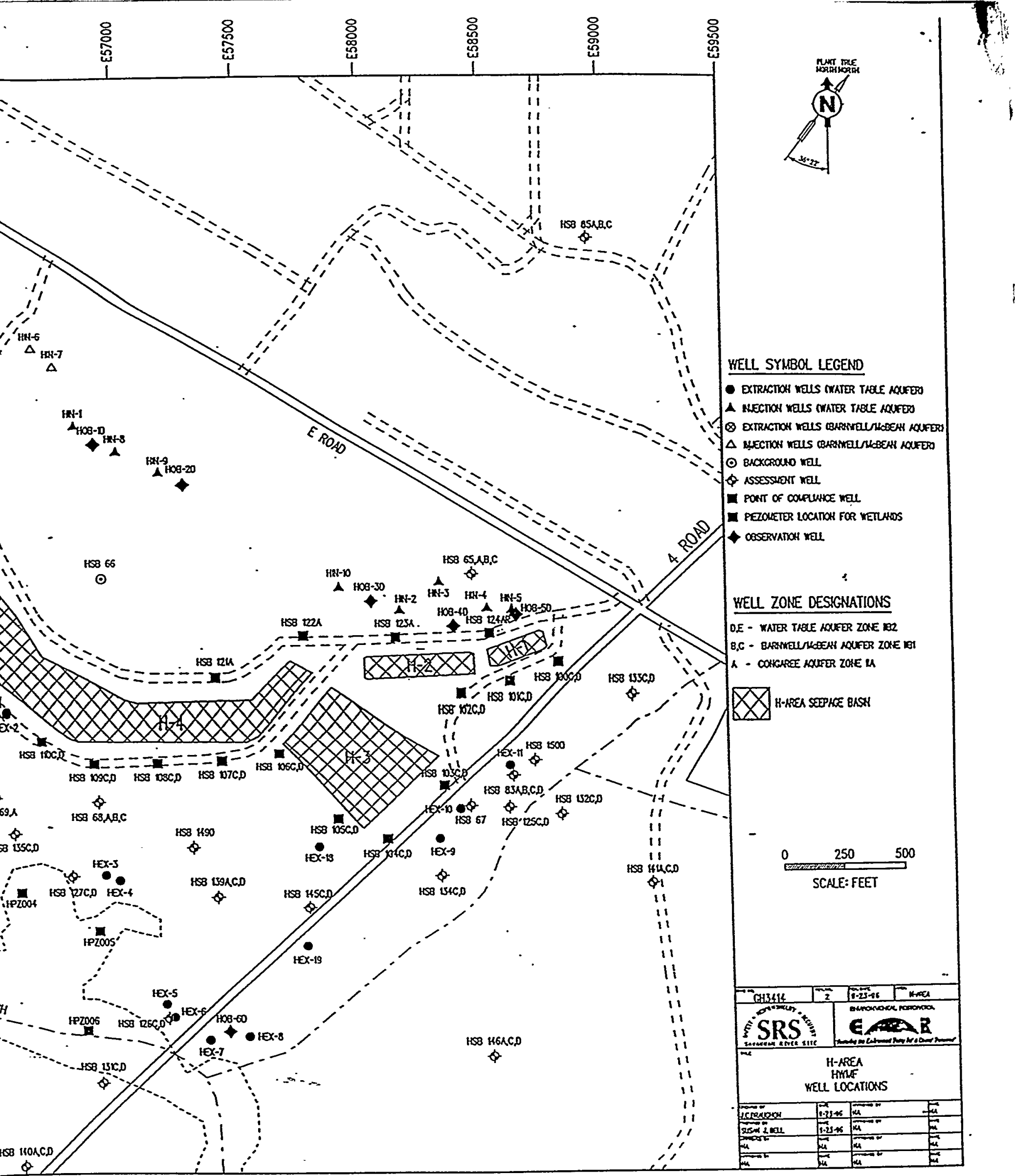




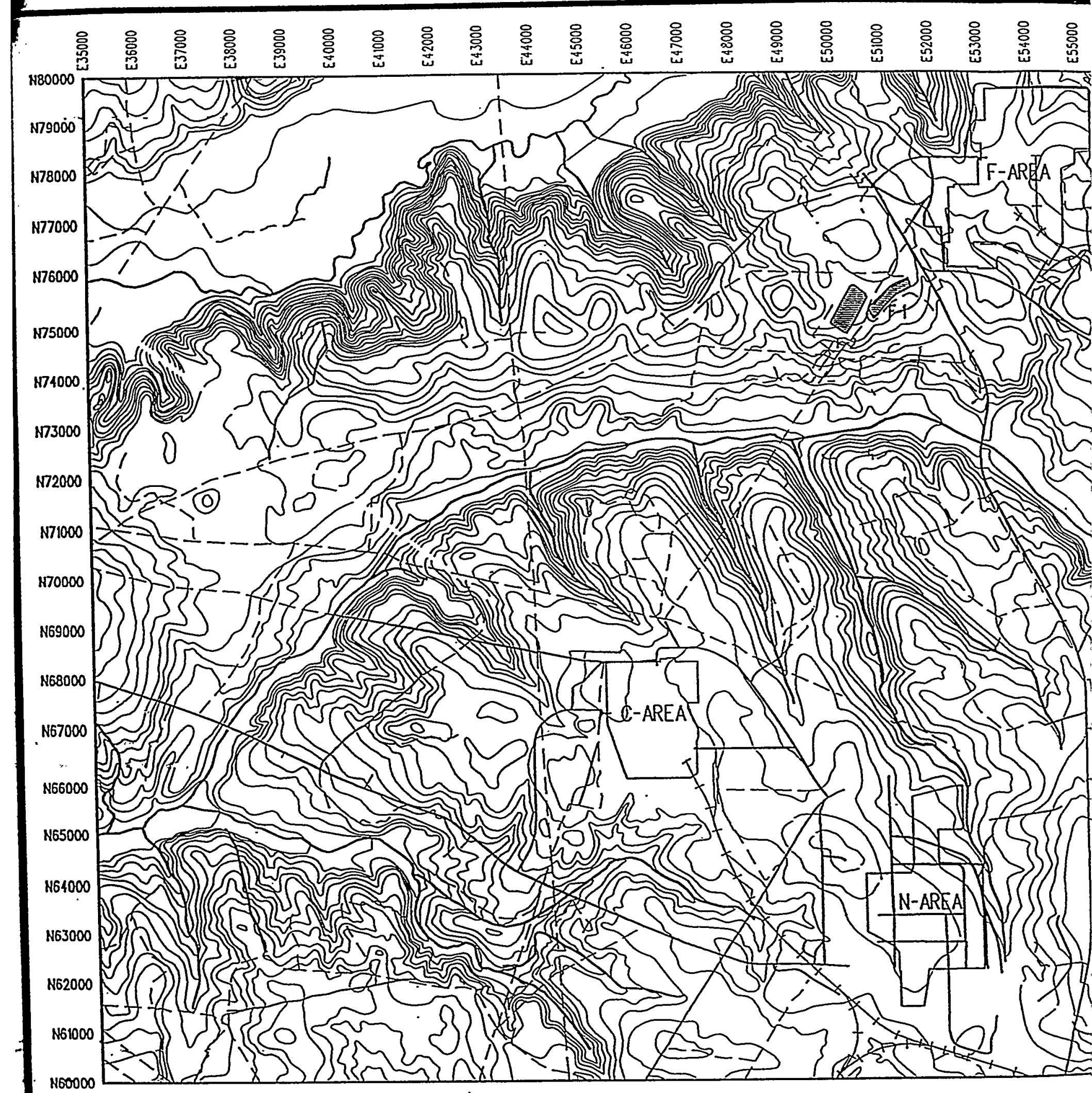

PIEZOMETER LOCATIONS

Figure 3. Reference piezometer locations. 


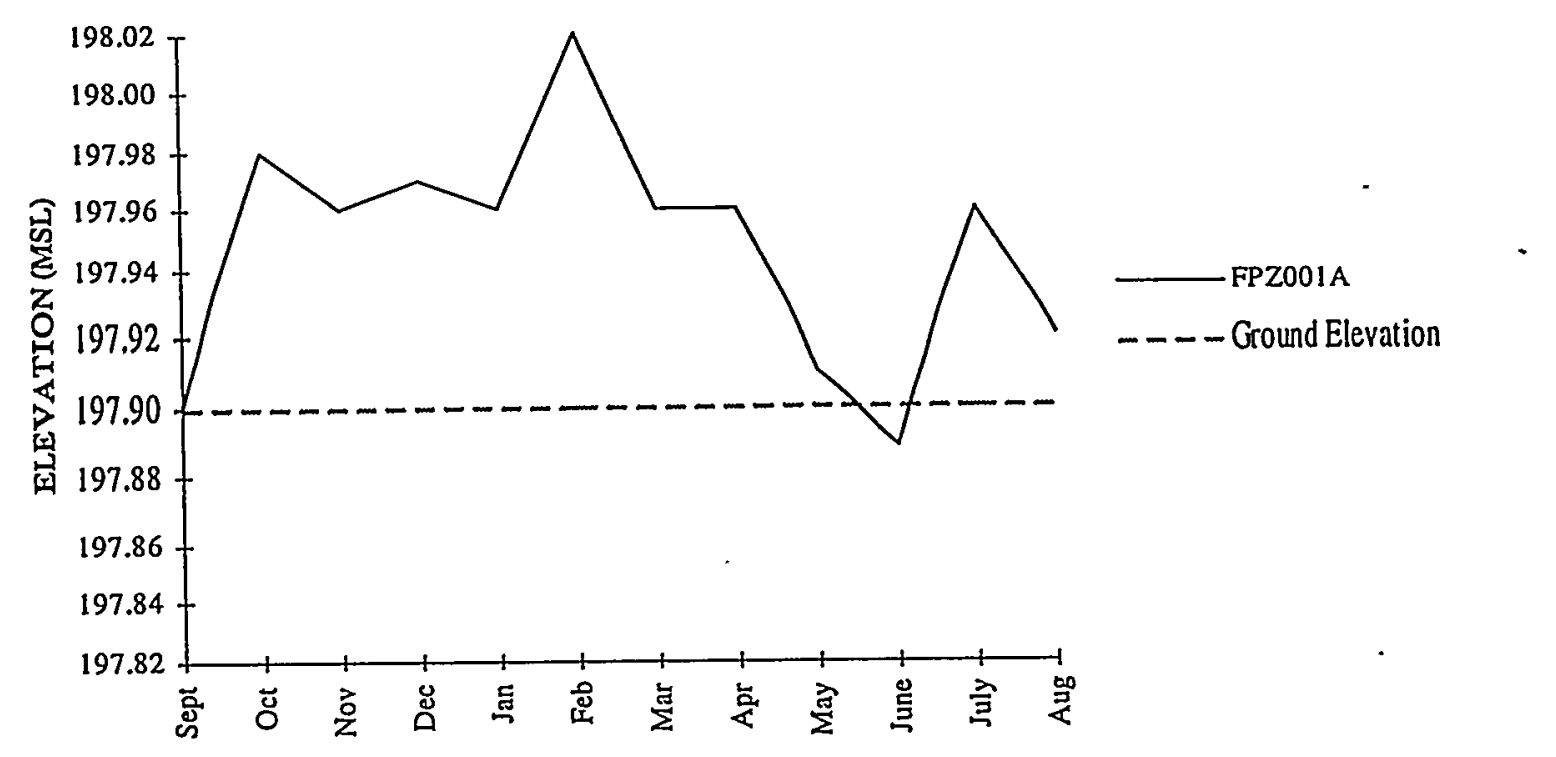

Figure 4. Monthly water level elevations at location FPZ001A.

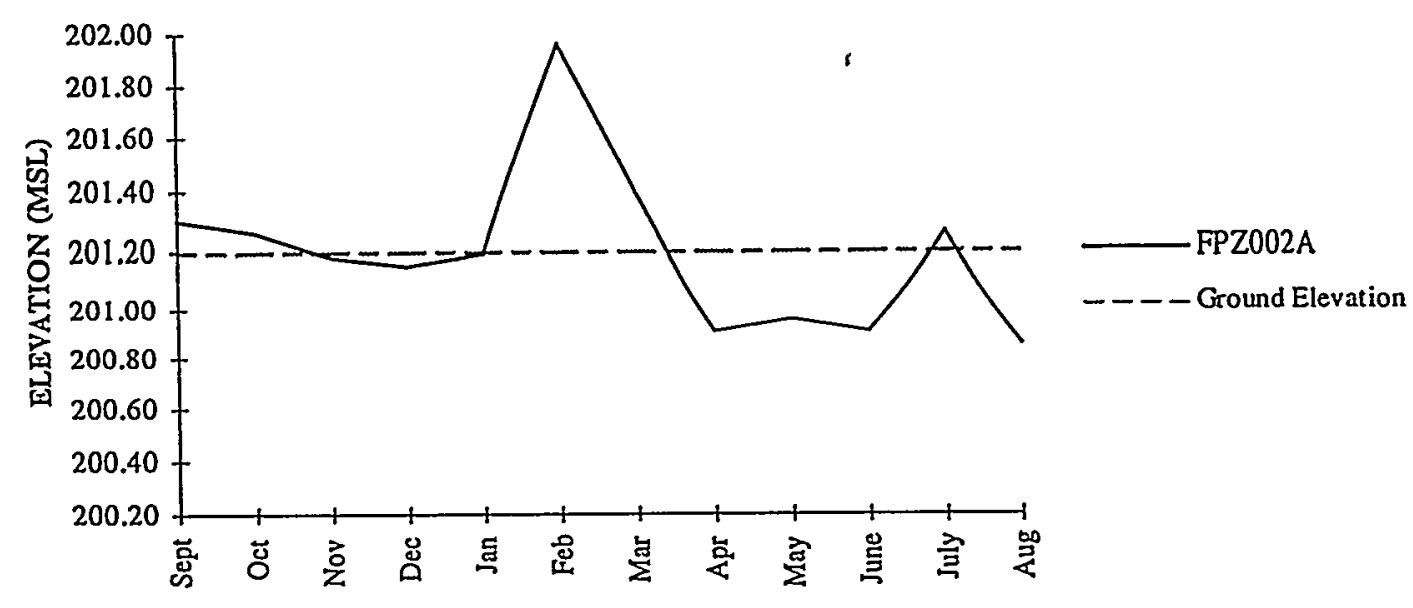

Figure 5. Monthly water level elevations at location FPZ002A. 


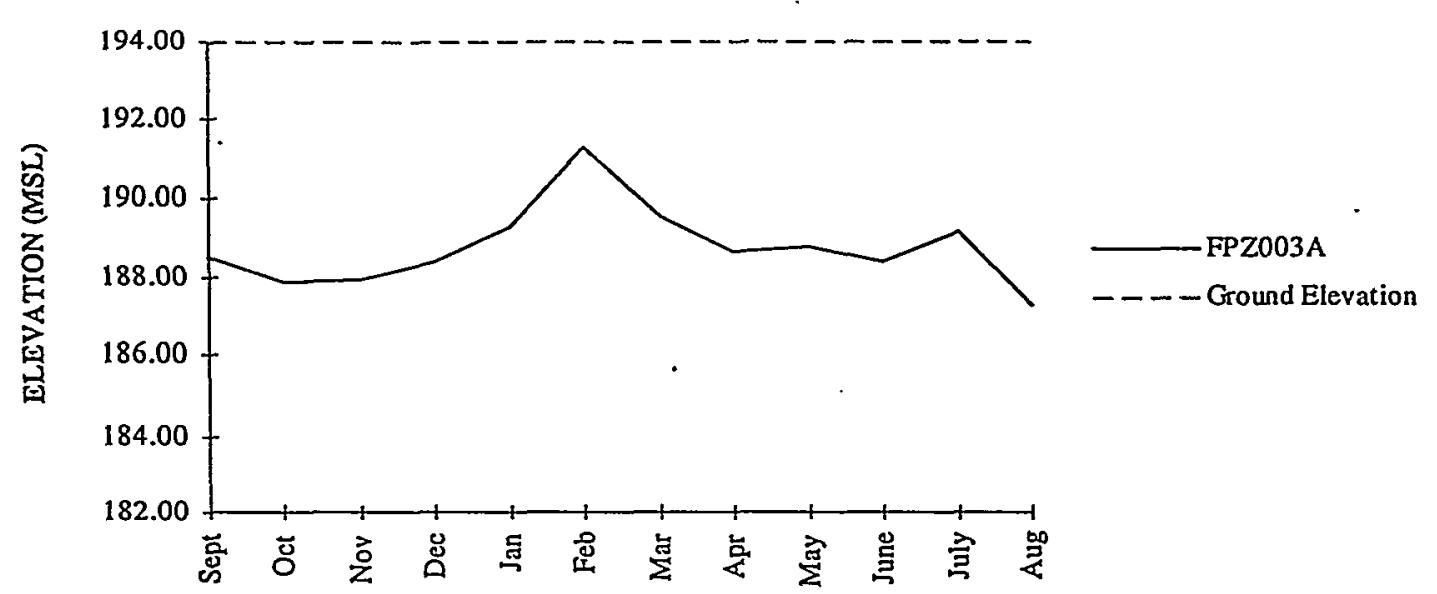

Figure 6. Monthly water level elevations at location FPZ003A.

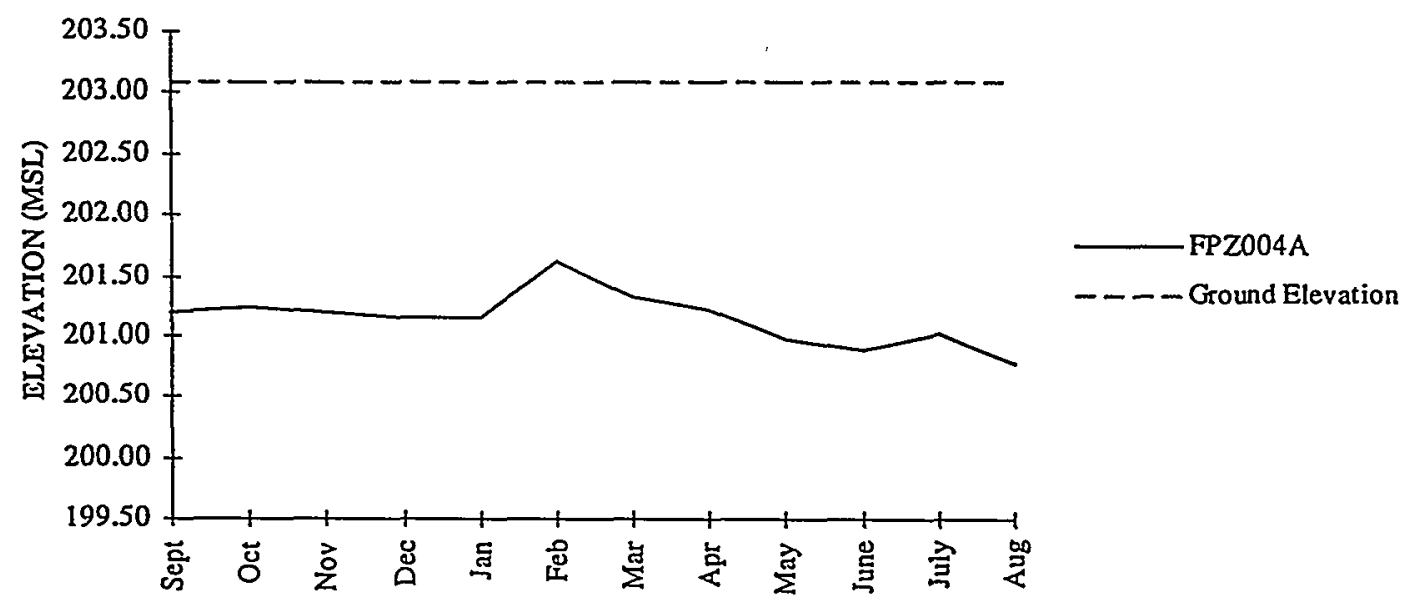

Figure 7. Monthly water level elevations at location FPZ004A. 


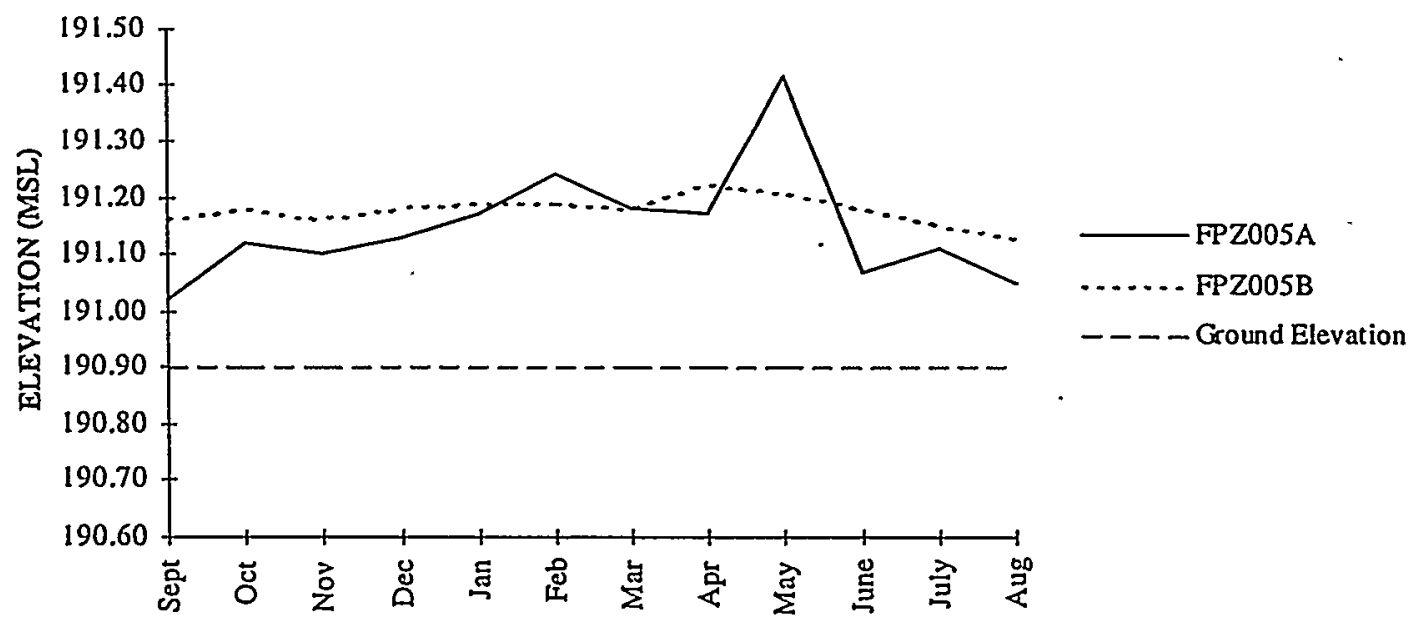

Figure 8. Monthly water level elevations at location FPZ005A and FPZ005B

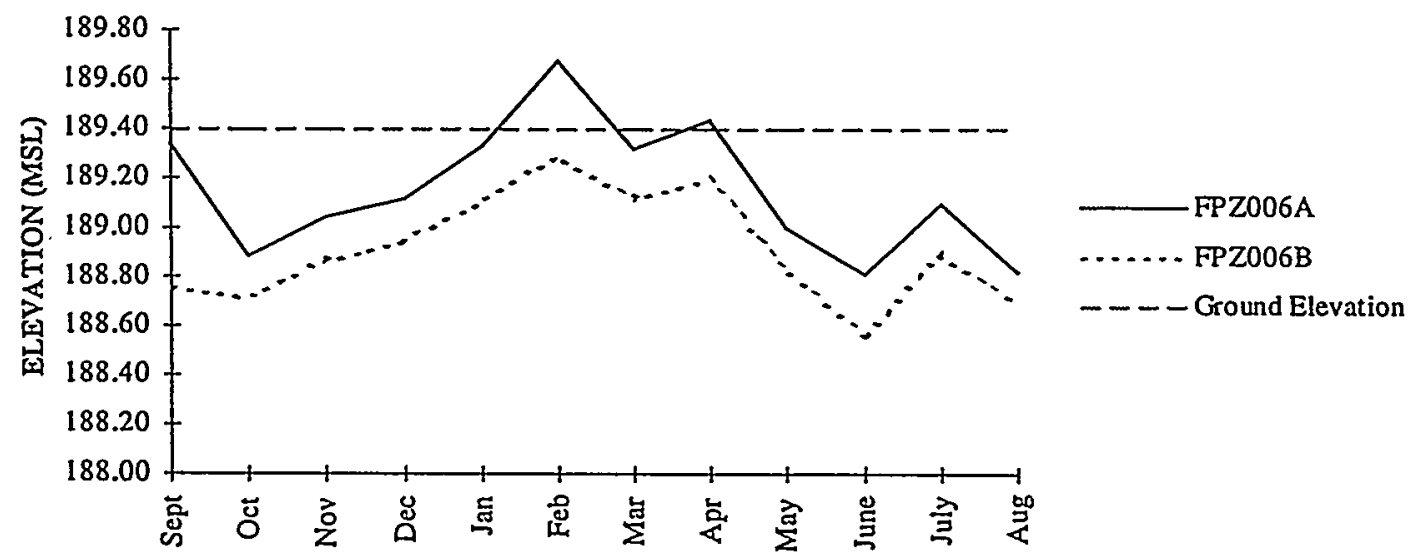

Figure 9. Monthly water level elevations at location FPZ006A and FPZ006B 


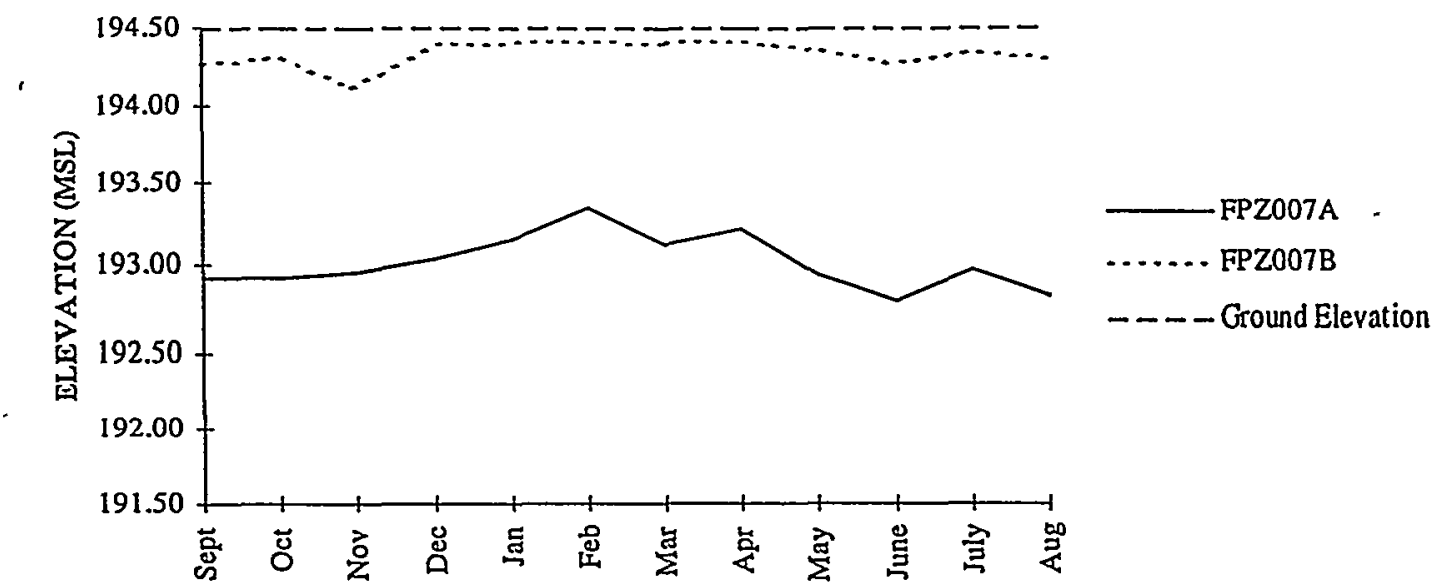

Figure 10. Monthly water level elevations at location FPZ007A and FPZ007B

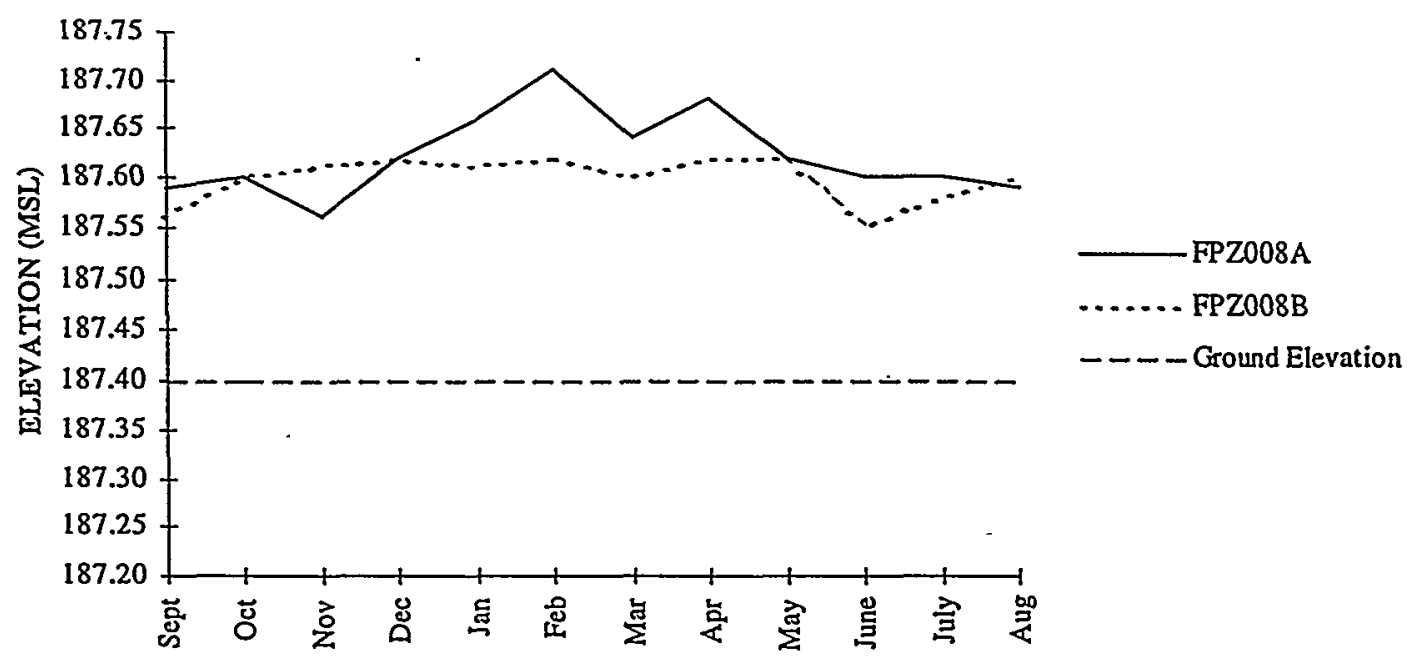

Figure 11. Monthly water level elevations at location FPZ008A and FPZ008B 


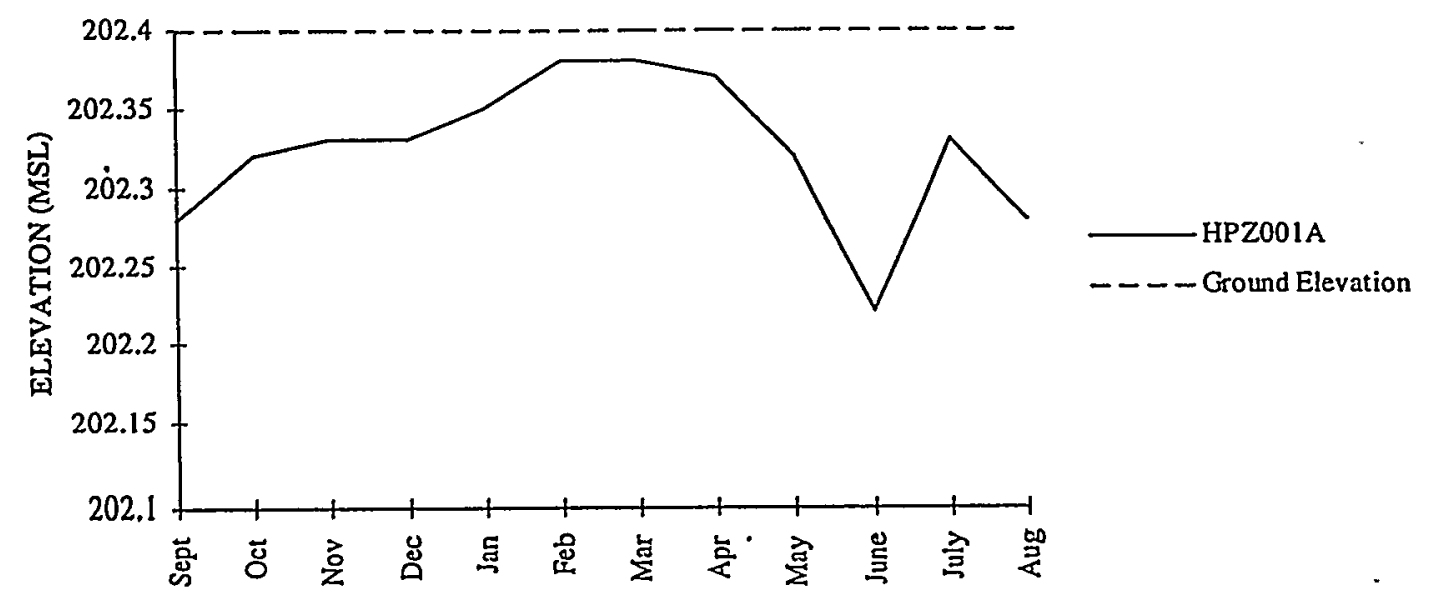

Figure 12. Monthly water level elevations at location HPZ001A

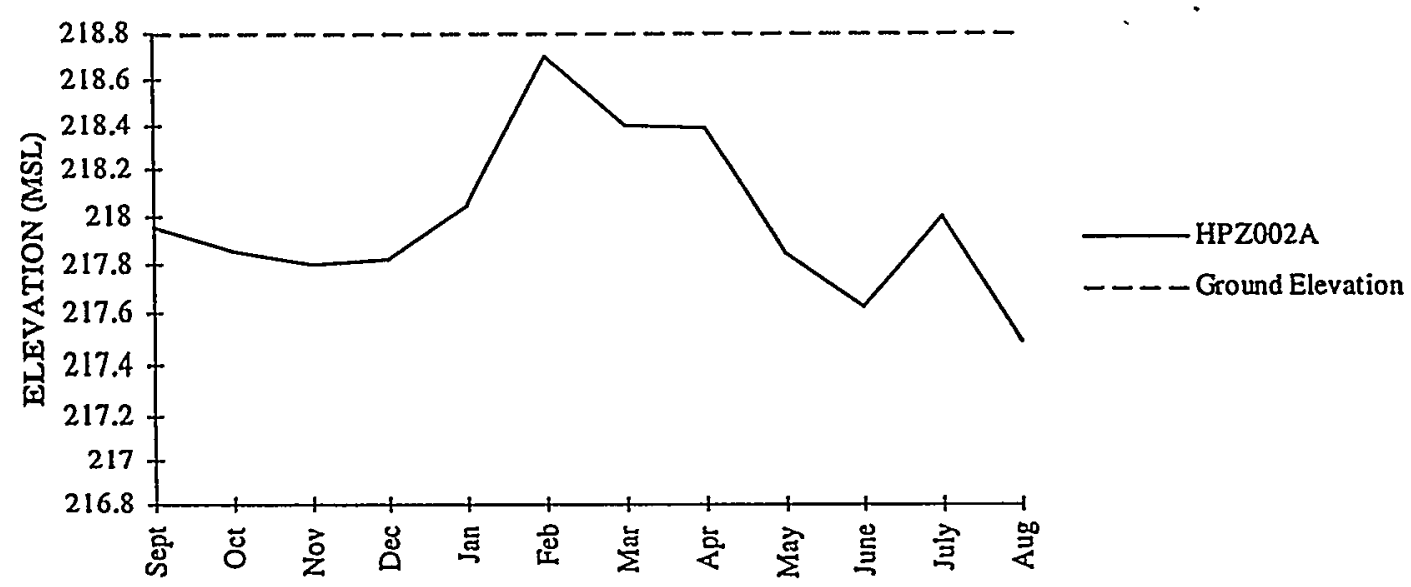

Figure 13. Monthly water level elevations at location HPZ002A 


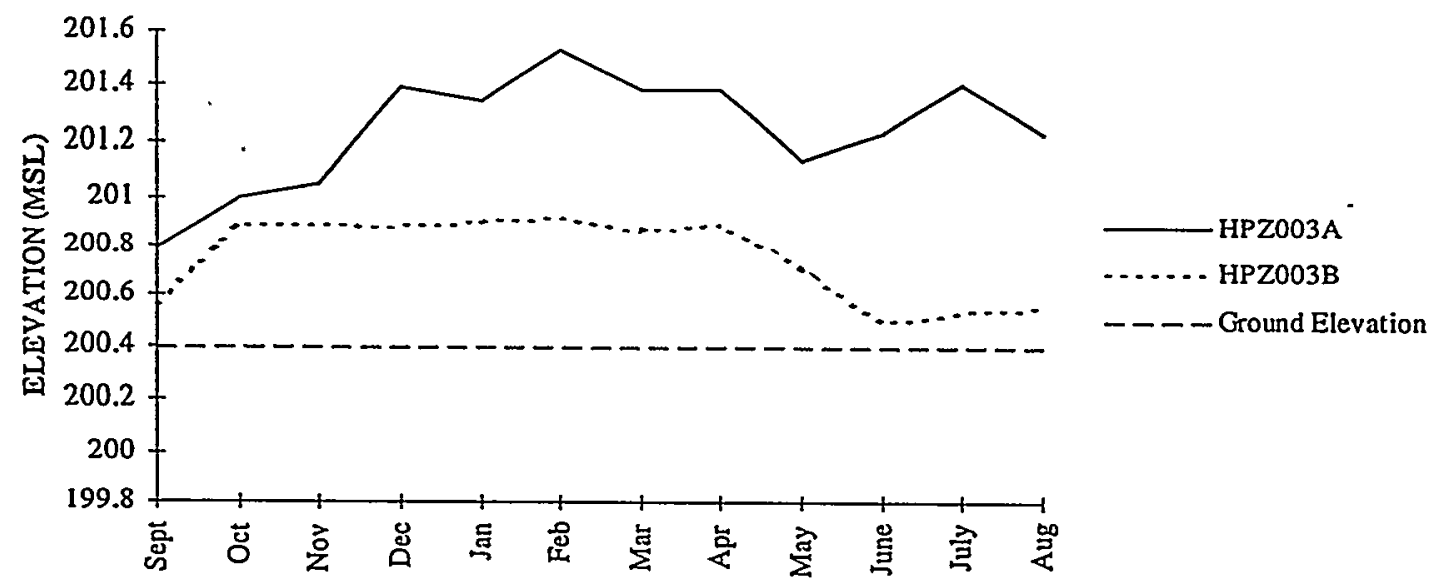

Figure 14. Monthly water level elevations at location HPZ003A and HPZ003B

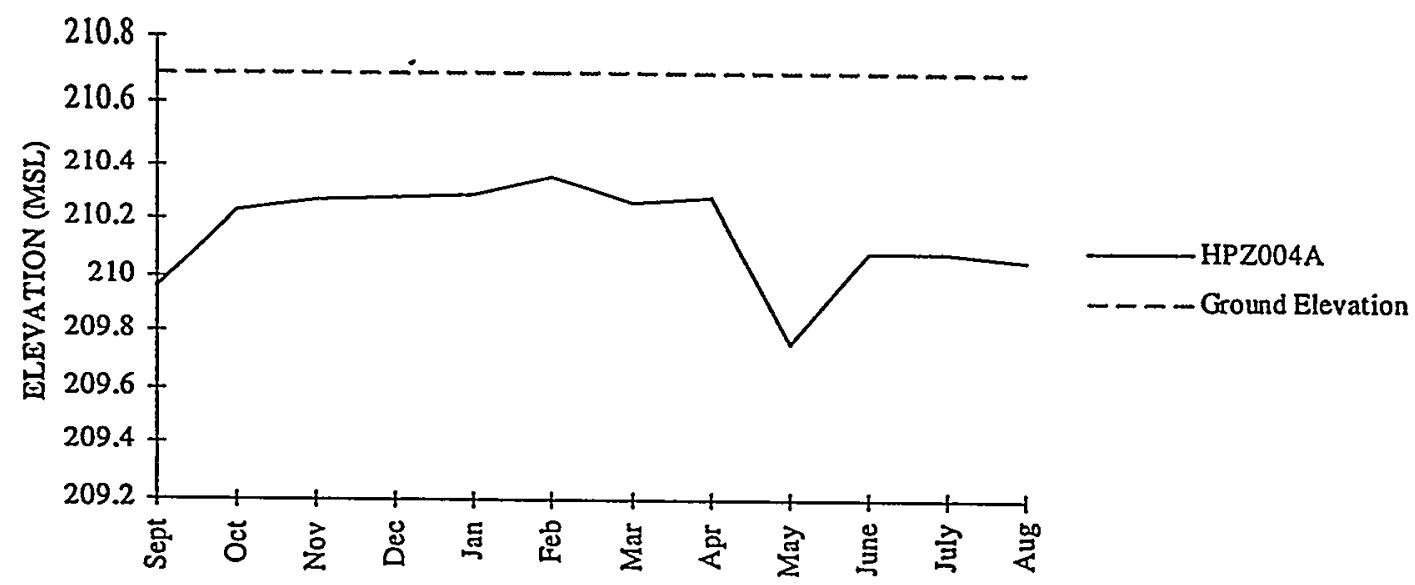

Figure 15. Monthly water level elevations at location HPZ004A 
ELEVATION (MSL)

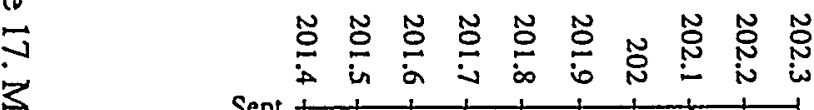

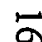

家

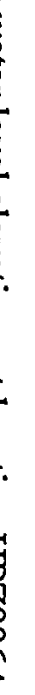
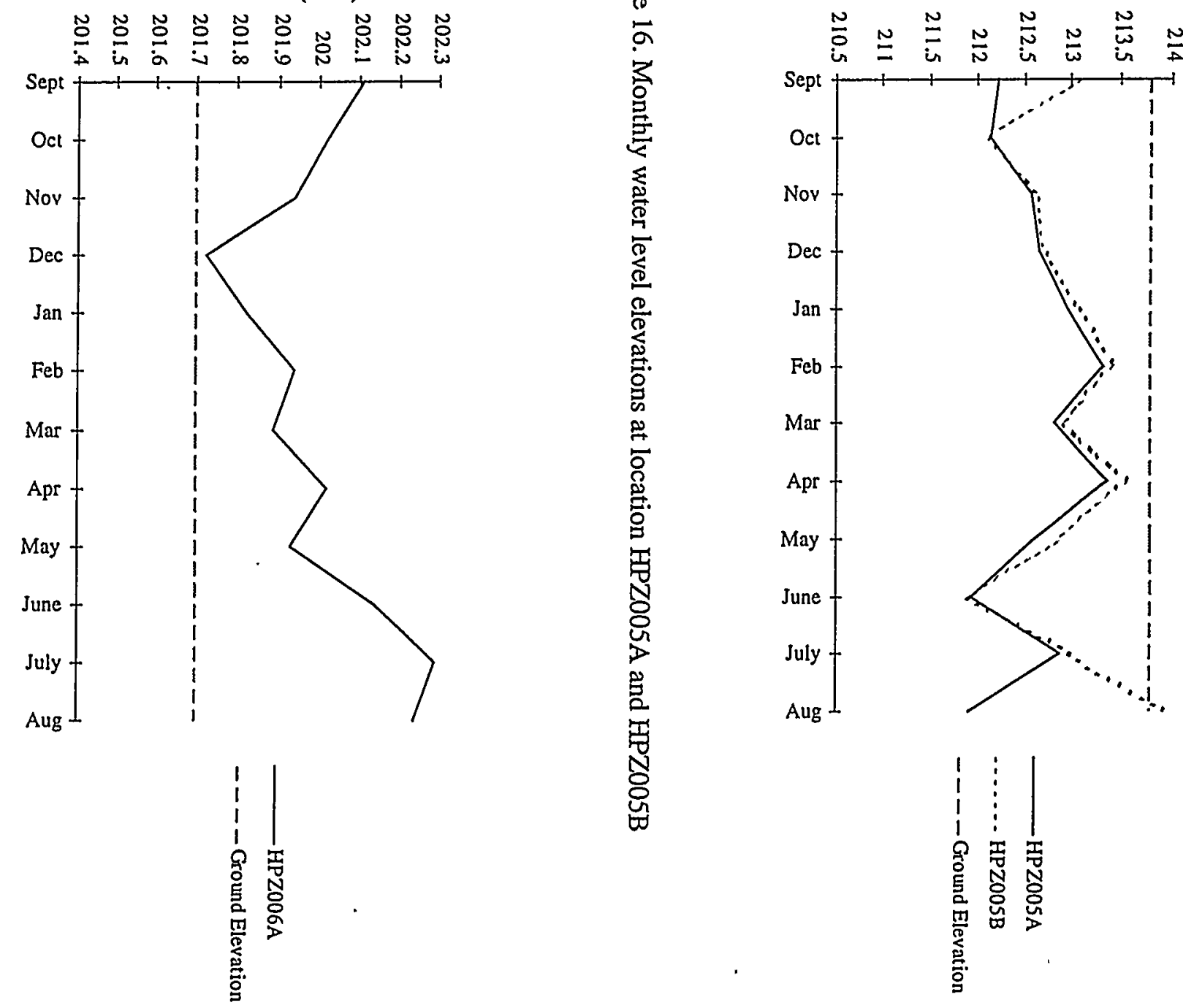


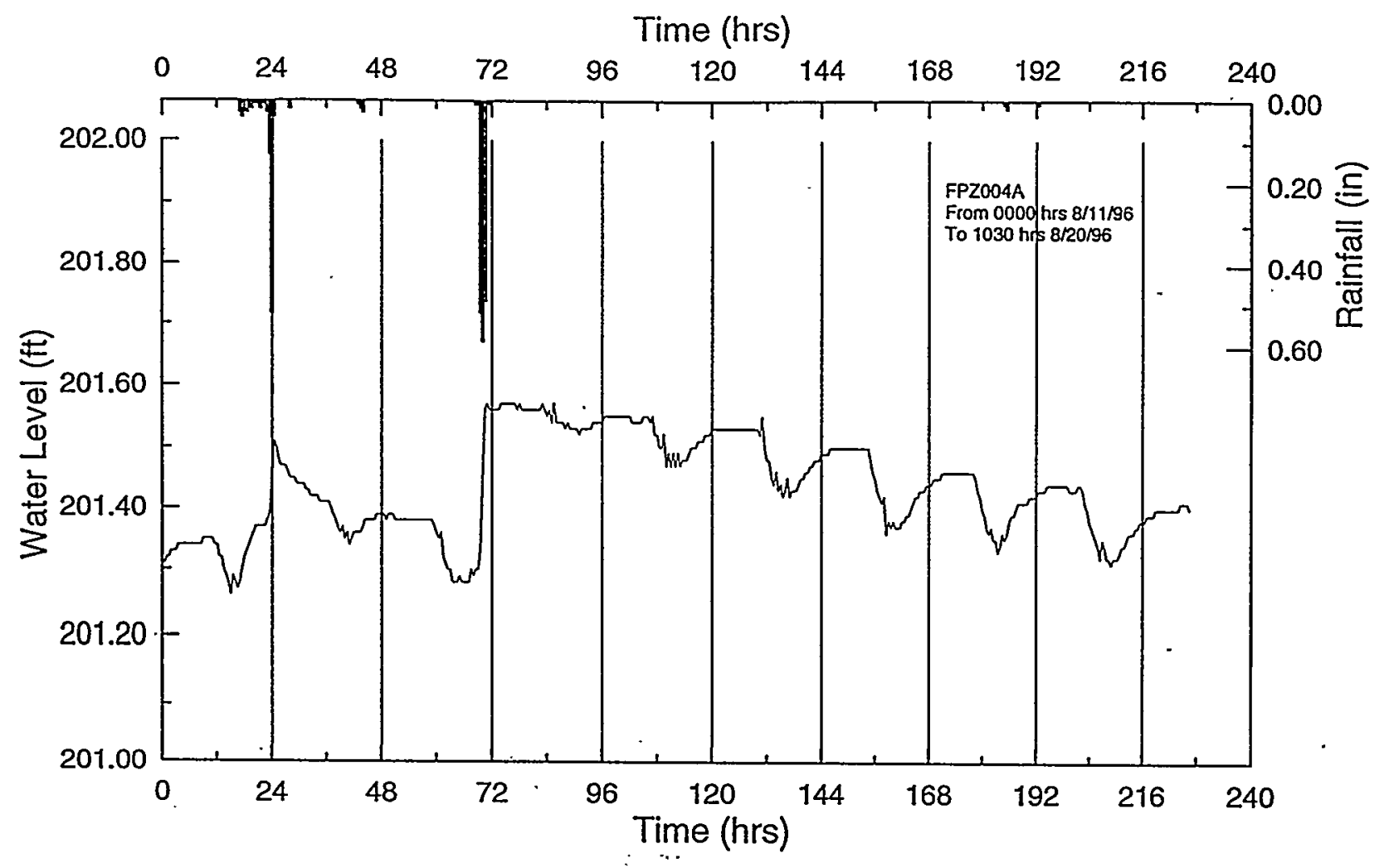

Figure 18. Continuous water level measurements taken from FPZ004A.

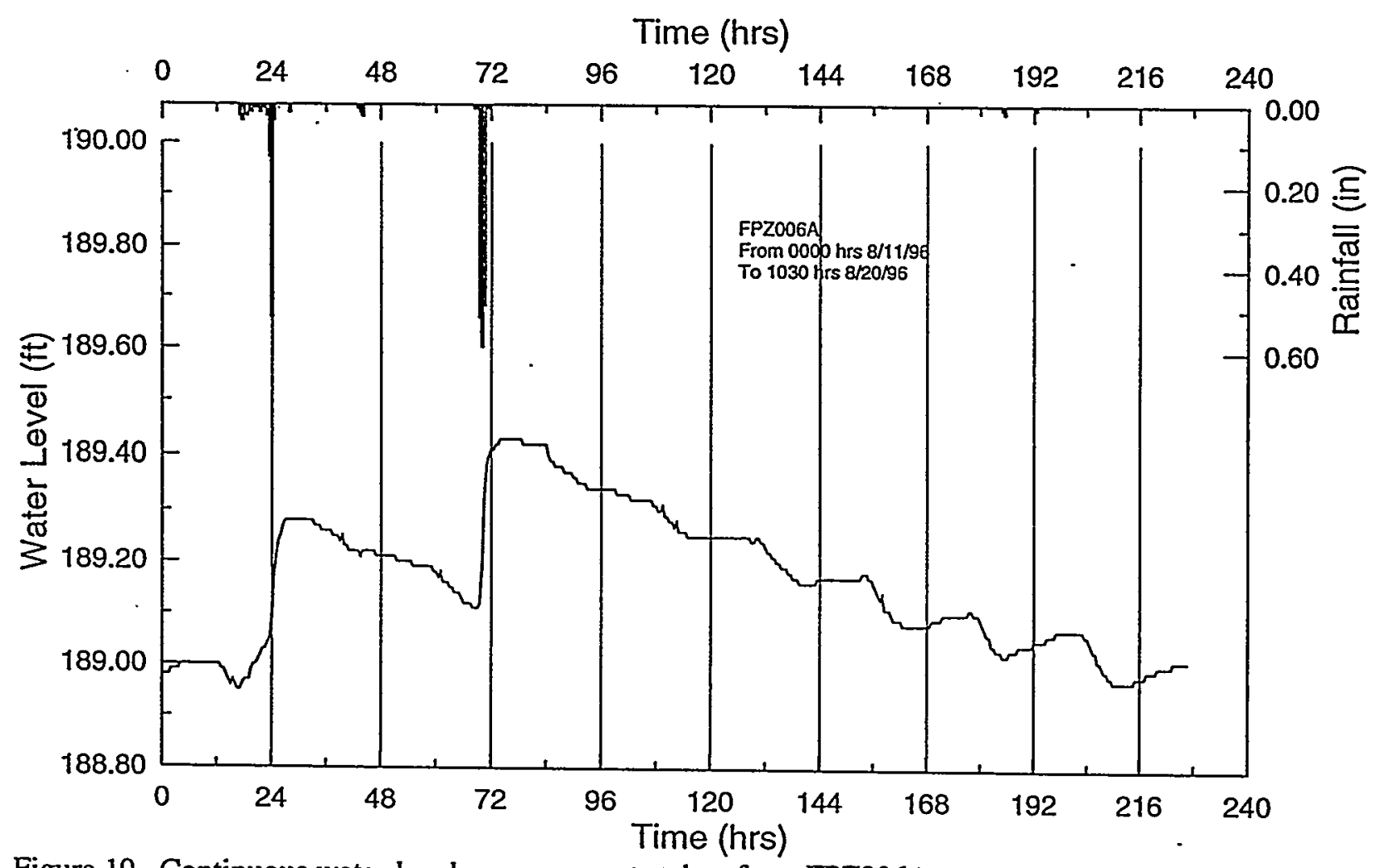

Figure 19. Continuous water level measurements taken from FPZ006A. 